\title{
The Impact of Administrative Empowerment on the Performance of King Abdul-Aziz Hospital in Makkah City (An Applied Study)
}

\author{
Ali Ahmed Ibrahim Asiri' ${ }^{1}$, Omar Al Sharqi ${ }^{2}$ \\ ${ }^{1}$ Health Management Specialist, King Abdul-Aziz Hospital, Makkah, Saudi Arabia \\ ${ }^{2}$ Faculty of Economics and Administration, KAU, Jeddah, Saudi Arabia \\ Email: ali.ahmad.asiri@gmail.com
}

How to cite this paper: Asiri, A. A. I., \& Al Sharqi, O. (2020). The Impact of Administrative Empowerment on the Performance of King Abdul-Aziz Hospital in Makkah City (An Applied Study). Journal of $\mathrm{Hu}$ man Resource and Sustainability Studies, 8, 157-184.

https://doi.org/10.4236/jhrss.2020.82010

Received: June 1, 2020

Accepted: June 26, 2020

Published: June 29, 2020

Copyright $\odot 2020$ by author(s) and Scientific Research Publishing Inc. This work is licensed under the Creative Commons Attribution International License (CC BY 4.0).

http://creativecommons.org/licenses/by/4.0/

\begin{abstract}
The study aims to identify the effect of administrative empowerment through the (knowledge, Authorization, work teams) concept on the performance of King Abdul-Aziz hospital in Makkah City. This aim is achieved through the views of study sample about the effect of administrative empowerment on the performance according to the variables: job title, academic qualification, years of experience, gender and nationality. The researcher has used the descriptive analytical method and used the questionnaire as a tool for study. The researcher used the simple random sampling where the sample consisted of (330) individuals. The main result of this study is showing that the individuals agree about the impact of administrative empowerment in term of knowledge on performance at King Abdul-Aziz Hospital, also most of the individuals agree in general about "the impact of administrative empowerment in term of authorization on performance, other result showing that most of the individuals agree in general about" the impact administrative empowerment in term of work team on performance. The main recommendation of the study is to maintain administrative empowerment in terms of knowledge, Authorization, and work teams due to their positive impact on performance. The researcher recommended further studies on the subject as there is scarcity in such studies in the local environment of the Kingdom of Saudi Arabia.
\end{abstract}

\section{Keywords}

Empowerment, Performance, Knowledge, Authorization, Work Teams

\section{Introduction}

The various administrative institutions are experiencing major and changes in 
their strategies and plans as a result of the major changes in economic activity, and the emergence of new data such as globalization, increasing of complexity degree, technological change and increasing of competition and knowledge intensity. In order to improve the ability of these institutions to adapt with these new variables and respond to the requirements of this change, institutions' management needs to focus on applying some concepts, including comprehensive quality management, competitive advantage, knowledge management and administrative empowerment, and the latter depends on the human being ability, the extent of his efficiency and the way to deal with them by the institution's management, where a necessary need has arisen to take care of developing his capabilities, directing, motivating, empowering him and set him free, confident and able to work without direct interference from the institution's management in which he works (Brown \& Harve, 2006).

Therefore, empowering employees may lead to develop the performance rates for the institution, through developing the employees' capabilities, providing them with confidence to work, delegating greater powers to them and giving them more freedoms for creativity. This will lead to developing their capabilities and raising their job performance rates and this reflects positively on the institution's performance itself, and that is what the administrative institutions seek. The empowerment has been known as "a strategy aims to liberate the potentialities of individuals, and involving them in the processes of building the organization, considering that the success of the organization depends on the harmony of individuals needs with the organization's vision and distant goals" (Brown \& Harve, 2006: p. 241). In another context, the administrative empowerment, the results of its implementation and application leads to increasing and strengthening the performance rates of administrative institutions (Al Otaibi, 2013).

\section{The Study Problem:}

There are a lot of researchers who addressed, through their studies, the topic of empowerment, and here the researcher tries to present some results of those studies, which clarified some of the negatives that these studies showed, and from those studies, (Baird \& Wang, 2009) pointed to some obstacles that accompany the application of empowerment in the administrative institution, where they indicated that despite the many benefits related to administrative empowerment, there are many obstacles related to activating that system within the institutions, including obstacles related to the employee himself in terms of his inability to carry out the tasks and responsibilities assigned to him.

In the same context, and from the reality of the researcher's work in King Abdul-Aziz hospital in Makkah City, the officials are concerned with improving the performance of the hospital's departments and sections and to develop them by creating the appropriate job climate and by applying modern administrative concepts, however, the researcher found through his personal observation in the hospital the absence of applying the concept of administrative empowerment in hospital departments and sections, which the researcher believes that this is one of the reasons for the poor efficiency and effectiveness of the hospital's perfor- 
mance. Therefore, this study tries through an analytical study to read the reality of applying administrative empowerment on the performance in King Abdul-Aziz hospital in Makkah City.

\section{Study Questions:}

1) What is the effect of administrative empowerment through the (knowledge) concept on the performance of King Abdul-Aziz Hospital in Makkah?

2) What is the effect of administrative empowerment through the (Authorization) concept on the performance of King Abdul-Aziz Hospital in Makkah?

3) What is the effect of administrative empowerment through the (work teams) concept on the performance of King Abdul-Aziz Hospital in Makkah?

4) What are the views of study sample about the effect of administrative empowerment on the performance of health organizations through studying the case of King Abdul-Aziz Hospital in Makkah according to the variables: job title, academic qualification, years of experience?

This study basically depends on the descriptive analytical approach which uses descriptive, statistical, and analytical methods. The descriptive approach is defined as "a set of research procedures integrated to describe the phenomenon or topic based on the collection, classification, processing and analysis of facts and data sufficiently and accurately in order to reveal significance and results" ( $\mathrm{Mu}-$ tawi \& Khalifa, 2014: p. 111).

\section{Literature Review}

\section{Defining the Concept of Administrative Empowerment:}

This study attempts to address the concept of empowerment in general and the concept of administrative empowerment in a more specific way and to know the views of some researchers on empowerment and similarities between those definitions, where the term empowerment is one of the modern terms in management science that have received the attention of organizations and administrative leaders and it reflects the process of giving individuals a broader authority to exercise control, responsibility, and use of their abilities, and by encouraging them to make decisions in its broadest sense, Tjosvold \& Sun's (2006) study, which dealt with the relationship between organizational support and employee empowerment, has reached an important conclusion indicating that successful employee empowerment requires the provision of effective organizational support. In the context (Ratmawati, 2007: p. 556) defined administrative empowerment as "the transfer of responsibilities and authority from managers to employees of the organization to participate in the decision-making authority, and in empowerment, the potential subordinate is responsible for the quality of his decision." Empowerment is also defined as "the administrative process by which employees are taken care of by enriching their information, knowledge and increasing their skills, developing their individual capabilities, and encouraging them to participate and provide the necessary capabilities to them in a way that motivates them to take appropriate decisions" (Al-Rashoudi, 2009: p. 10). 
Empowerment is also known as "liberating a person from restrictions, encouraging and motivating the individual, and rewarding him for exercising the spirit of initiative and creativity" (Melhem, 2006: p. 6), also (Mohammadia, 2016: p. 11) defined it as "Granting employees within the Jordan Tourism Revitalization Authority broad freedom in career work by expanding the scope of authority authorization and increasing participation in decision-making, self-motivation, and emphasizing the importance of the work environment, and building trust between management and employees, which encourages their creative behavior," and also defined as "the process of exchanging information and the necessary knowledge that enables employees to contribute in Organizational Performance" (Kruja et al., 2009: p. 29).

It was also known as "the skill of giving employees the power to set goals for their own works, decision-making, and solve problems related to the powers vested to them and within the limits of their responsibilities", (Littrell, 2003: p. 2), also it is "an organizational strategy that includes giving employees full authority and responsibility in making decisions related to their works." (Al-Madi \& Nusairat, 2011: p. 527), it was also defined as "a strategy that aims to liberate the individual's capacities and engaging them in the organization building processes, given that the success of the organization depends on the harmony of individuals' needs with the organization's vision and distant goals." (Brown \& Harvey, 2006: p. 241). So, the researcher concludes that administrative empowerment can be defined as empowering individuals with all the details of the administrative process, developing their capabilities, qualifying them, and involving them in making and taking decisions for the institution and granting them powers to move through it and appoint them in the appropriate place.

There is a lot of Studies about defining the concept of administrative empowerment, one of these studies is the study of (Irechukwu, 2010), the results of these study concluded that the principals have attributes that qualify them and enable them to practice leadership work in the school, and that they also have a good ability to communicate positively with all members of the educational process, including teachers, students and parents, and that they are well aware of teaching methods and all these features make them successful educational leaders. also the study of (Liszt, 2008), the results concluded that, in general, the new york department of education develops the decision-making authority of the principals as they feel that they are responsible for students' academic results for all students, also managers explained that the decision-making authority has enabled managers to achieve the distinction of education, which contributes significantly to achieving success in the academic achievement of students. Also the study of (Latifa, 2015), the study recommendations, is the most important of which are: The official side in the work by giving the employees a wide range of power with the participation in decision-making, also (Affana, 2013) study about the administrative empowerment and its relationship with the effectiveness of the work teams the results showed that there is a disparity in approval ratings between the five 
variables identified by the survey of managerial empowerment while (Al Otaibi, 2004) study concluded that the promoting of Administrative empowerment decreases the work turnover and therefore, providing qualified nurse staff.

\section{The Importance of Administrative Empowerment:}

Giving employees the freedom to work, giving them more powers, developing their capabilities, and involving them in the decision-making process in the organization. All this means their participation in the administrative process of the institution, and therefore looking to lead the institutions towards achieving their goals, so the completeness of this image, from the point of view of the administrative leadership, is an importance for the institution. Some researchers have summarized that importance, (Al-Sharif, 2015: p. 21) indicated the importance of the empowerment process for several justifications, such as the organization's need to respond to circumstances and emergency variables, reducing the number of managerial levels in organizational structures, senior management focus on long-term strategic issues, the necessity of optimizing the use of all available resources, especially human resources, to preserve the development and excellence of the organization, the importance of cost reduction and rapid decision-making, unlocking creative and innovative capabilities of individuals, strengthening contentment, affiliation, and job motivation and giving individuals a greater responsibility and a sense of accomplishment in their work.

There is a lot of Studies about defining the importance of administrative empowerment, one of these studies is the study of (Baird \& Haiyin, 2009), the results showing that each of the cultural factors such as teamwork and organizational factors such as training and association with bonuses have a clear impact on the general level of employee empowerment adaptation. also the study of (Yoon, Kim, \& Shin, 2016), the study concluded that there is a harmonic relationship between trust in authorization with practical skill and transformational leadership and thus reflected positively on the provision of high quality care for patients of long-term hospital care, also study of (Mustafa, 2016) the results were identified that participants employee empowerment score was at a moderate level and organizational stress score was high.

Also other Study of (Ozaralli, 2003), study concluded that there is a statistically significant relationship between administrative empowerment and organizational creativity and the prevailing communication pattern in the organization, and that the transformational leadership pattern has a great role in promoting the concept of administrative empowerment and that it helps in increasing the effectiveness of task forces in providing the opportunity to make decisions. And the study of (AlMadhi \& Nusairat, 2011) the impact of administrative, empowerment on the Application of total quality management, results of the study, the study did not find statistically significant differences in the attitudes of respondents towards adopting the concept of total quality management due to their demographic characteristics with the exception of the functional level variable. 


\section{Administrative Empowerment Dimensions:}

Any administrative process has elements and dimensions that constitute its structure, and administrative empowerment like many administrative terms and processes have many elements and dimensions lies mainly in the professional training, teamwork, creative behavior development, self-motivation, and imitation and simulation (Al-Dosari, 2014: pp. 53-99; Al-Ruwaiq, 2016: pp. 230-258).

While, (Karen, 2006), proposes four approaches to empower employees administratively; employee participation in decision-making, employee participation in planning processes, providing employees with continuous organizational training and support, and continuous praises for good employees. As for (Henkink, 2005: p. 260), he identified four dimensions of empowerment, summarized in impact, efficiency, choice and meaning of work.

There is a lot of studies about defining empowerment dimensions, one of these studies is the study of (Yang \& Choi, 2009), which results is showed that more than $80 \%$ of the respondents answered that their teams have a great degree of responsibility, knowledge and creativity by giving them freedom and independence and their participation in the decision-making of the institution; and other study of (Harrim \& Alkshali, 2008), the dimensions of empowerment were (impact, freedom to act, meaning, competition) while dimensions of work teams' effectiveness were (performance, innovation, communication, use of resources), and the results of the study concluded that there is a clear impact of empowerment on the effectiveness of the work team.

Study of (Mohammadia, 2016) the study recommended: Adopt functional empowerment approach administratively in the Jordan Tourism Board, so as to raise awareness of this aspect, because of its importance in guiding the creative behavior of employees towards creativity and organizational strengthening, and (Aisha, 2016) the results the study found to confirm hypotheses where he found that there is a correlation between the various administrative empowerment dimensions (the authorization of authority, work teams, training, effective communication, motivation) and organizational creativity, study also recommended that the adoption of small and medium-sized enterprises administrative departments of the concept of empowerment in all its dimensions.

\section{Administrative Empowerment Obstacles:}

The administration's endeavor to empower employees administratively must face several challenges and obstacles, and those challenges could be environmental, human, or organizational, and despite the many benefits of administrative empowerment, "There are many obstacles to activating that system within institutions, including obstacles related to the employee himself in terms of his inability to carry out the tasks entrusted to him" (Baird \& Wang, 2009), and (Al-Sabti \& Qureshi, 2015; Hassan, 2008) have added some obstacles, including organizational obstacles, administrative obstacles, human obstacles, technical obstacles, and external environment obstacles.

As for (Forrester, 2000: p. 67), he pointed out the obstacles of empowerment that managers do not want to apply the concept of empowerment, due to their 
fear of losing power and influence, equality between the concepts of empowerment and authorization of authority, and considering authorization as synonymous with empowerment, and implementing empowerment by transferring and simulating successful empowerment programs in other organizations despite the different circumstances of each organization, and not taking into account the needs of the participants in the authority.

\section{Institutional Performance:}

The administrative process that accompanies the job performance is the one that constitutes the performance of the institution, and if the balance of any of the previous elements is disturbed, then undoubtedly this will lead to an imbalance in the institution's path and its institutional performance. Then, the basis is the job performance of employees and how to develop it and increase its rates because it will led to raise the performance rates of the institution, and the concept of performance indicates that it is the performance that exceeds the level of current and expected performance through effective investment of the available resources in the organization and the possession of a competent leadership, and performance is considered one of the most important hubs of professional work in any functional field, and if this performance is unique in a work environment where justice and equality prevails, then it is logical for this performance to take its owner to a prominent position in the organization in which he works.

There is a lot of studies about defining Institutional Performance, one of these studies is the study of (Al-Rabadi, 2009), the result showing there is a statistically significant effect of empowering employees on Institutional performance, in addition to the absence of a statistically significant effect of empowering employees on institutional performance due to personal variables (gender, age, educational qualification, job title), while there are statistically significant differences with respect to the variable of work experience. Other study for (Talib, 2014). The study results: there is a linear interrelationship between the administrative empowerment variables (training, giving the required information, authorization of authority, participation, and organizational performance variables). Customer Service, (customer loyalty) the study recommended increasing attention to the administrative empowerment process as it has a prominent role in improving organizational performance.

\section{Defining the Concept of Performance:}

Many researchers addressed performance through many hubs, each according to its environment and practical drivers, but all performance definitions were similar, as they constitute common elements and dimensions that are found to measure the dimensions of the employee's performance and the performance of the administrative institution itself, many researchers have addressed that. Performance has been defined as "Management ability to convert the organization's inputs into a number of outputs with specific specifications and at the lowest possible cost since the performance does not depend on the amount of effort exerted only but rather depends on the capabilities, skills, and awareness of the staff to play the role that must be done" (Al-Sakhl et al., 2010: p. 14). So, it is as- 
sumed that many administrative institutions in the Kingdom have introduced modern information systems to develop the job performance of employees, in addition to the introduction of modern technologies in administrative work in these institutions.

The job performance was defined as "a function of the ability to carry out the tasks assigned to the employee and the desire to perform these tasks to advance and raise the level of the organization's performance" (Al-Azzawi \& Jawad, 2010: p. 16), and the performance was defined as "the organization's ability to continue and survive, achieving a balance between the satisfaction of shareholders and employees, and we conclude from this definition that performance is a measure of judgment on the extent to which the organization achieves its main goal, which staying in its market and continuing its activity, in light of competition, and then the organization is able to maintain a balance in rewarding both shareholders and employees" (Al-Dawi, 2010: p. 218).

The "implementation of creative work procedures that enable the organization to reach the highest level of performance and in the long run" (Gittell et al., 2010: p. 495). "The outstanding performance is achieved through the organization's possession of a supportive culture to make the employees bear the responsibility to carry out the tasks assigned to them to promote lasting organizational success, and the researchers have emphasized that outstanding performance represents the highest level that individuals can achieve through their high mental and intellectual capabilities" (Akdemir et al., 2010: p. 150). So, through previous definitions, the researcher believes that the concept of performance is the result of an individual's efforts that begins with abilities, role realization, the tasks, and thus the concept of performance refers to the degree of achievement and completion of the tasks entrusted to the individual and then performance is measured, and the researcher defines it procedurally as a set of practical duties, activities and tasks assigned to individuals that should be performed and accomplished to the fullest extent.

\section{Elements of Job performance:}

Performance is like any job or administrative term that has many of the elements that make up it, and performance consists of a group of elements which referred to by (Abu Sharkh, 2010: p. 20), the most important of which are: knowledge of job requirements, quality of work, amount of work accomplished, and perseverance.

\section{Factors Affecting Performance and Its Determinants:}

The individual performance effects of the job tasks are divided into certain factors that distinguish the individual as a result of internal personal courses such as competencies, previous training courses, or internal training in the institution and personal study through reading everything new related to the job, (Abu Sharkh, 2010: p. 20) indicated the performance determinants, divided into three types; Informative knowledge, Procedural and skill knowledge and Motivation and stimulation. 
The researcher found study (Obeid, 2009) about the reality of administrative empowerment and its impact on workers, the study reached a set of results was the most important Empowerment was not clearly defined, due to changes in the organizational structure of the objectives to serve the personal interests of a particular category. The study concluded a set of recommendations, the most important of which are: The need to be in accordance with the work requirements. also the study (Al Shara'a, 2009), study results showing the level of performance of employees for the official role was high, while the level of performance of employees for the additional role was average, while it was found that there were no statistically significant differences in the respondents' responses to the level of staff performance of the behaviors of both the formal role and the addition.

\section{Performance Dimensions:}

Performance includes the dimensions included in this concept, where some focus on the economic aspect of performance, while others intend to take into account the organizational and social aspect, and this is from the premise that performance is a comprehensive concept, represented according to (Al-Dawi, 2010: p. 19) in Organizational dimension of performance, and Social dimension of performance.

\section{Research Methodology}

\section{Data Collection Methodology:}

According to (Kothari, 2004) the questionnaire is regarded as the most extensively used method in various economic, business and social surveys. Kothari (2004) investigated that the questionnaire as a method of data collection is quite popular, particularly in cases of big enquires. It is being adopted by private individuals, research workers, private and public organizations and even by governments. In this method a questionnaire is sent (usually post) to the persons concerned with a request to answer the questions and return the questionnaire, a questionnaire consists of a number of questions printed or typed in a definite order or form of set of forms, and the respondents have to answer the questions on their own.

There are also various definitions cited for questionnaire as a method of data collection. (Pandey \& Pandey, 2015) defined the questionnaire is a systematic compilation of questions that are submitted to a sampling of population from which information is desired. That means the questionnaire is from prepared and distributed to secure responses to certain questions. It is a device for securing answers to questions by suing a form which the respondent will fill by himself. Moreover, "questionnaires, if properly formulated, will not normally require high skill and sensitivity to answer in comparison with in-depth or semi-structured interviews" (Jankowicz, 2005). Furthermore, the questionnaire was also defined by (Ranjit Kumar, 2011) as a written list of questions, the answers to which are recorded by respondents. Therefore, in the questionnaire respondents read the questions, interpret what is expected and then write down the answers. 
In order to collect the needed data for this research, the study use the secondary resources in collecting data such as books, journals, statistics and web pages, in addition to preliminary resources that not available in secondary resources through distribute questionnaires on study population in order to get their opinions about "The impact of administrative empowerment on employee performance".

Research methodology depends on the analysis of data on the use of descriptive analysis, which depends on the poll and use the main program (SPSS).

\section{Population and Sampling:}

The study population consists of doctors, nurses, technicians and administrators working at King Abdul Aziz Hospital in Makkah City. And the total numbers reach (2313) individuals. By applying the equation:

The researcher is used the following Statistical equation to collect sampling (Krejcie, R.V., \& Morgan, equation):

$$
S=\frac{\chi^{2} N P(1-P)}{d^{2}(N-1)+\chi^{2} P(1-P)}
$$

where:

$S$ : Represents the required sample size;

$\chi$. It is the value of the Chi square at the degree of freedom 1, at the confidence level, where it has a value of (3.841);

$N$ : Is the size of the study population of (2313);

$P$. The percentage of the adjective in society $=0.5$;

$d$ : It is the degree of accuracy and its value is (0.05).

By applying the above equation:

$$
S=\frac{3.841 \times 2314 \times 0.5 \times 0.5}{0.05^{2} \times 2313+3.841 \times 0.5 \times 0.5}=\frac{2222.0185}{6.74275}=329.54=330
$$

Thus, the sample size appropriate for the study becomes (330) singles.

\section{Criterion Related Validity:}

\section{Internal consistency:}

Internal consistency of the questionnaire is measured by a scouting sample, which consisted of fifteen questionnaires, through measuring the correlation coefficients between each question in one field and the whole filed. Table 1 below shows the correlation coefficient and $p$-value for each field items. As show in the table the $p$-values are less than 0.05 or 0.01 ,so the correlation coefficients of this field are significant at $\alpha=0.01$ or $\alpha=0.05$, so it can be said that the paragraphs of this field are consistent and valid to be measure what it was set for.

\section{Cornbrash's Coefficient Alpha:}

This method is used to measure the reliability of the questionnaire between each field and the mean of the whole fields of the questionnaire. The normal range of Cornbrash's coefficient alpha value between 0.0 and +1.0 , and the higher values reflects a higher degree of internal consistency. As shown in Table 2 bellow the Cornbrash's coefficient alpha was calculated. The general reliability for all items in each sections ranges from $(0.651-0.935)$. This range is considered high; the result ensures the reliability of the questionnaire. 
Table 1. Correlation coefficient between each question and the whole questionnaire.

\begin{tabular}{cccc}
\hline Question No. & Pearson coefficient & Question No. & Pearson coefficient \\
\hline 1 & $0.404^{* *}$ & 13 & $0.133^{*}$ \\
2 & $0.159^{* *}$ & 14 & $0.312^{* *}$ \\
3 & $0.350^{* *}$ & 15 & $0.325^{* *}$ \\
4 & $0.220^{* *}$ & 16 & $0.324^{* *}$ \\
5 & $0.402^{* *}$ & 17 & $0.340^{* *}$ \\
6 & $0.447^{* *}$ & 18 & $0.352^{* *}$ \\
7 & $0.213^{* *}$ & 19 & $0.412^{* *}$ \\
8 & $0.347^{* *}$ & 20 & $0.145^{* *}$ \\
9 & $0.385^{* *}$ & 21 & $0.245^{* *}$ \\
10 & $0.383^{* *}$ & 22 & $0.123^{* *}$ \\
11 & $0.302^{* *}$ & 23 & $0.142^{* *}$ \\
12 & $0.451^{* *}$ & 24 & $0.324^{* *}$ \\
\hline
\end{tabular}

Table 2. The Cornbrash's Coefficient Alpha of impact administrative empowerment on performance at King Abdul-Aziz Hospital in Makkah City.

\begin{tabular}{ccc}
\hline $\begin{array}{c}\text { The impact administrative empowerment on } \\
\text { performance at King Abdul-Aziz Hospital in Makkah }\end{array}$ & No. questions & Cronbach's \\
\hline Knowledge & 6 & 0.715 \\
Authorization & 6 & 0.703 \\
Work teams & 6 & 0.674 \\
Performance & 6 & 0.751 \\
No. of all questionnaire $=24$ & Cranach's Alpha $=0.795$ \\
\hline
\end{tabular}

\section{Statistical Tools:}

To achieve the research goal, researcher used the statistical package for the Social Science (SPSS) for Manipulating and analyzing the data.

- Frequencies and Percentile.

- Alpha-Cranach Test for measuring reliability of the items of the questionnaires.

- Person correlation coefficients for measuring validity of the items of the questionnaires.

- Independent sample t test to test the difference between the means of samples.

- One-way ANOVA test for the difference between means three samples or more.

\section{Data Analysis}

\section{Population and Sampling:}

The population consists of the employees, medical staff and physician's working at the King Abdul-Aziz Hospital in Makkah, 330 Questionnaires were distributed to the research population, all questionnaires are received, and the following tables illustrated the properties of the samples: 


\section{Experience:}

Table 3 shows that $47 \%$ from the sample their years' experience from 10 to 15 years, $23.9 \%$ are from 15 to over years, and $17.6 \%$ of them from 5 to 10 years, $11.5 \%$ are from 1 to 5 years. Figure 1 shows these percentages.

\section{Education:}

Table 4 shows that $46.4 \%$ from the sample's education level was "Bachelor", flowed by Diploma with (32.1\%), Master degree 14.8\%, Secondary with (3.9\%), and $2.7 \%$ are $\mathrm{PhD}$. Figure 2 show these percentages.

\section{Job title:}

Table 5 shows that $30.3 \%$ from the sample their job is "Doctor", $18.2 \%$ their job title was employer, $16.4 \%$ their job title is "Health technician", $14.5 \%$ their job is "Nurse", $11.5 \%$ their job title was Specialist, and $9.1 \%$ their job title was Pharmacist. Figure 3 shows these percentages.

\section{Gender:}

Table 6 shows that $80.9 \%$ from the sample are "Male", 19.1\% are "Female". Figure 4 shows these percentages.

\section{Nationality:}

Table 7 shows that $86.4 \%$ from the sample their nationality is "Saudi", $12.1 \%$ are "Non-Saudi". Figure 5 shows these percentages.

Table 3. Show the experience.

\begin{tabular}{ccc}
\hline Ages range & Frequency & Percent \\
\hline From 1 to 5 years & 38 & 11.5 \\
From 5 to 10 years & 58 & 17.6 \\
From 10 to 15 years & 154 & 47.0 \\
From 15 to over & 79 & 23.9
\end{tabular}

Table 4. Show education.

\begin{tabular}{ccc}
\hline Education level & Frequency & Percent \\
\hline secondary & 13 & 3.9 \\
Diploma & 106 & 32.1 \\
Bachelor & 153 & 46.4 \\
Master. & 49 & 14.8 \\
PhD & 9 & 2.7 \\
\hline
\end{tabular}

Table 5. Show job title.

\begin{tabular}{ccc}
\hline Job title & Frequency & Percent \\
\hline Doctor & 100 & 30.3 \\
Specialist & 38 & 11.5 \\
Pharmacist & 30 & 9.1 \\
Nurse & 48 & 14.5 \\
Health technician & 54 & 16.4 \\
Employer & 60 & 18.2
\end{tabular}


Table 6. Show gender.

\begin{tabular}{ccc}
\hline Gender & Frequency & Percent \\
\hline Male & 267 & 80.9 \\
Female & 63 & 19.1 \\
\hline
\end{tabular}

Table 7. Show nationality.

\begin{tabular}{|c|c|c|}
\hline Nationality & Frequency & Percent \\
\hline Saudi & 285 & 86.4 \\
\hline Non-Saudi & 40 & 12.1 \\
\hline
\end{tabular}

Figure 1. Show the percentages of experience.

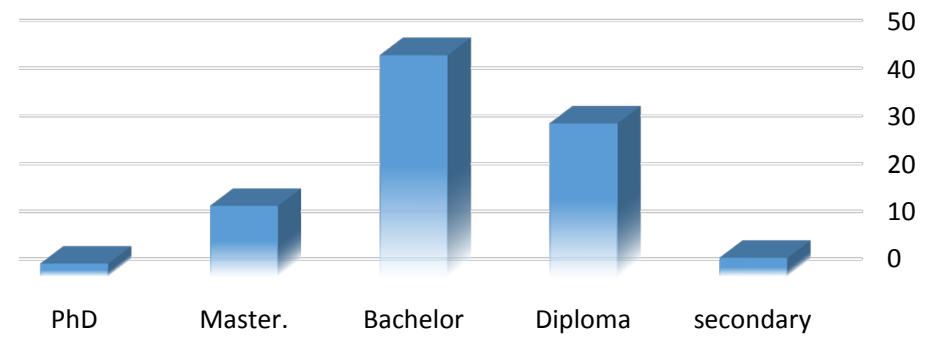

Figure 2. Show the percentages of education.

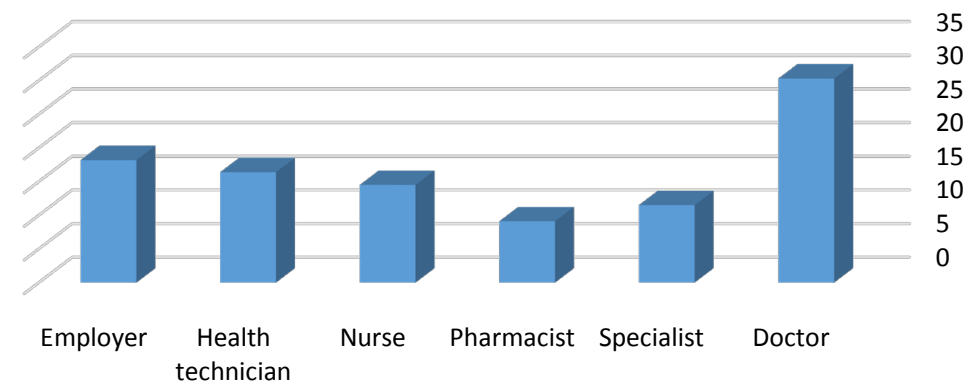

Figure 3. Show the percentages of job title.

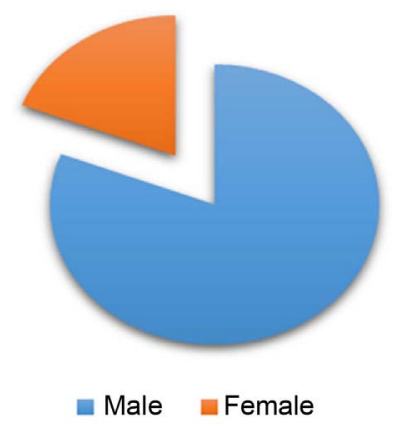

Figure 4. Show the percentages of gender. 


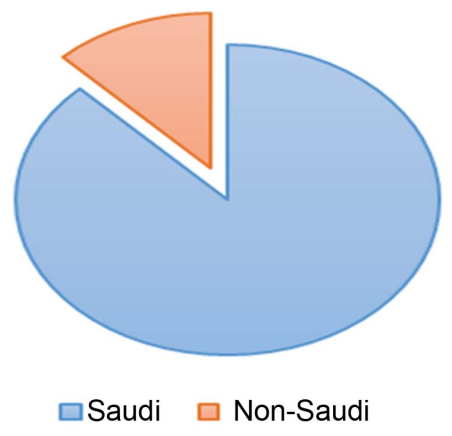

Figure 5. Show the percentages of nationality.

- The impact administrative empowerment in term of (knowledge) on performance at King Abdul-Aziz Hospital in Makkah City (Table 8):

1) In item (5) the weight mean equal " 3.82 " and $p$-value equal " 0.000 " which is less than 0.05 , that (The working procedures, regulations and instructions are distinguished by clarity and transparency in the hospital, which positively affects performance), is agree.

2) In item (1) the weight mean equal " 3.61 " and $p$-value equal " 0.000 " which is less than 0.05 , that (The hospital administration allows employees to have easy access to information that helps them in work, which reflects positively on performance), is agree.

3 ) In item (6) the weight mean equal " 3.61 " and $p$-value equal " 0.000 " which is less than 0.05 , that (The hospital administration encourages workers to be creative and to develop their cognitive abilities, which positively affects performance), is agree.

4) In item (2) the weight mean equal " 3.33 " and p-value equal " 0.000 " which is less than 0.05 , that (The hospital administration provides effective and advanced means of communication for employees, which reflects positively on performance), is neutral.

$5)$ In item (4) the weight mean equal " 3.26 " and $p$-value equal " 0.000 " which is less than 0.05 , that (The workers share the new knowledge with the workers in other departments, which has a positive impact on performance), is neutral.

6) In item (3) the weight mean equal " 3.24 " and $p$-value equal " 0.000 " which is less than 0.05 , that (is a management information system that provides information quickly in the hospital, and this reflects positively on performance), is neutral.

According to general mean of these items which equal (3.48) greater than 3 (center point of likert measure) this indicate the general answer is moving towards the positive direction (agree).

- The impact of administrative empowerment in term of (Authorization) on performance at King Abdul-Aziz Hospital in Makkah (Table 9):

1) In item (1) the weight mean equal " 3.68 " and $p$-value equal " 0.000 " which is less than 0.05 , that (The hospital administration has a clear strategy for authorization of power, which reflects positively on performance), is agree. 
Table 8. The impact administrative empowerment in term of (knowledge) on performance at King Abdul-Aziz Hospital in Makkah City.

\begin{tabular}{|c|c|c|c|c|c|c|c|}
\hline No. & Items & Weight mean & standard deviation & Chi-square & $p$-value & Rank & Importance \\
\hline 5 & $\begin{array}{l}\text { The working procedures, regulations and instructions } \\
\text { are distinguished by clarity and transparency in the } \\
\text { hospital, which positively affects performance }\end{array}$ & 3.82 & 0.53 & 1103.09 & 0.000 & 1 & Agree \\
\hline 1 & $\begin{array}{l}\text { The hospital administration allows employees to have } \\
\text { easy access to information that helps them in work, } \\
\text { which reflects positively on performance }\end{array}$ & 3.61 & 0.56 & 316.93 & 0.000 & 2 & Agree \\
\hline 6 & $\begin{array}{l}\text { The hospital administration encourages workers to be } \\
\text { creative and to develop their cognitive abilities, which } \\
\text { positively affects performance }\end{array}$ & 3.61 & 0.56 & 126.39 & 0.000 & 3 & Agree \\
\hline 2 & $\begin{array}{l}\text { The hospital administration provides effective and } \\
\text { advanced means of communication for employees, } \\
\text { which reflects positively on performance }\end{array}$ & 3.33 & 0.59 & 277.15 & 0.000 & 4 & Neutral \\
\hline 4 & $\begin{array}{l}\text { The workers share the new knowledge with the workers } \\
\text { in other departments, which has a positive impact on } \\
\text { performance }\end{array}$ & 3.26 & 0.80 & 252.73 & 0.000 & 5 & Neutral \\
\hline 3 & $\begin{array}{l}\text { There is a management information system that } \\
\text { provides information quickly in the hospital, and this } \\
\text { reflects positively on performance }\end{array}$ & 3.24 & 0.63 & 622.15 & 0.000 & 6 & Neutral \\
\hline & All items & 3.48 & 0.61 & & & & Agree \\
\hline
\end{tabular}

Table 9. The impact of administrative empowerment in term of (Authorization) on performance in King Abdul-Aziz Hospital in Makkah City.

\begin{tabular}{|c|c|c|c|c|c|c|c|}
\hline No. & Items & Weight mean & standard deviation & Chi-square & $p$-value & Rank & Importance \\
\hline 1 & $\begin{array}{l}\text { The hospital administration has a clear strategy for } \\
\text { authorization of power, which reflects positively on } \\
\text { performance. }\end{array}$ & 3.68 & 0.62 & 581.03 & 0.000 & 1 & Agree \\
\hline 6 & $\begin{array}{l}\text { There are multiple powers for staff to act on the tasks } \\
\text { assigned to them, and this positively affects } \\
\text { performance. }\end{array}$ & 3.68 & 0.62 & 129.03 & 0.000 & 2 & Agree \\
\hline 2 & $\begin{array}{l}\text { The powers granted are commensurate with the } \\
\text { nature of jobs for the employees, which reflects } \\
\text { positively on performance }\end{array}$ & 3.45 & 0.63 & 405.91 & 0.000 & 3 & Agree \\
\hline 3 & $\begin{array}{l}\text { The hospital administration believes in participating } \\
\text { in decision-making by Authorization executive and } \\
\text { middle management and involving them in } \\
\text { decision-making }\end{array}$ & 3.36 & 0.74 & 303.39 & 0.000 & 4 & Neutral \\
\hline 4 & $\begin{array}{l}\text { The hospital staff, in the light of Authorization } \\
\text { granted to them, diagnose problems and propose } \\
\text { solutions, choose and evaluate them }\end{array}$ & 3.22 & 0.76 & 286.03 & 0.000 & 5 & Neutral \\
\hline 5 & $\begin{array}{l}\text { The hospital administration is confident in the staff s } \\
\text { abilities to perform the tasks assigned to them, which } \\
\text { reflects positively on the performance. }\end{array}$ & 3.20 & 0.86 & 218.85 & 0.000 & 6 & Neutral \\
\hline & All items & 3.43 & 0.71 & & & & Agree \\
\hline
\end{tabular}


2) In item (6) the weight mean equal " 3.68 " and p-value equal " 0.000 " which is less than 0.05 , that (There are multiple powers for staff to act on the tasks assigned to them, and this positively affects performance), is agree.

3 ) In item (2) the weight mean equal " 3.45 " and $p$-value equal " 0.000 " which is less than 0.05 , that (The powers granted are commensurate with the nature of jobs for the employees, which reflects positively on performance), is agree.

4) In item (3) the weight mean equal " 3.36 " and $p$-value equal " 0.000 " which is less than 0.05 , that (The hospital administration believes in participating in decision-making by delegating executive and middle management and involving them in decision-making), is neutral.

$5)$ In item (4) the weight mean equal " 3.22 " and p-value equal " 0.000 " which is less than 0.05, that (The hospital staff, in the light of Authorization granted to them, diagnose problems and propose solutions, choose and evaluate them), is neutral.

6) In item (5) the weight mean equal " 3.20 " and p-value equal " 0.000 " which is less than 0.05 , that (The hospital administration is confident in the staff's abilities to perform the tasks assigned to them, which reflects positively on the performance), is neutral.

According to general mean of these items which equal (3.43) greater than 3 (center point of Likert measure) this indicate the general answer is moving towards the positive direction (agree).

- The impact administrative empowerment in term of (work Team) on performance at King Abdul-Aziz Hospital in Makkah City (Table 10):

1) In item (1) the weight mean equal " 3.748 " and $p$-value equal " 0.000 " which is less than 0.05, that (In light of the job empowerment in the hospital, the employees feel that they work within one team, which positively affects performance), is agree.

2 ) In item (6) the weight mean equal " 3.748 " and $p$-value equal " 0.000 " which is less than 0.05 , that (The management devised a system of self-monitoring on the work of individuals and teamwork, which positively affects performance), is agree.

3 ) In item (2) the weight mean equal " 3.515 " and $p$-value equal " 0.000 " which is less than 0.05, that (The ideas and suggestions of employees in light of their special empowerment are taken seriously when making decisions regarding their work, which positively affects performance), is agree.

4) In item (3) the weight mean equal " 3.382 " and p-value equal " 0.000 " which is less than 0.05, that (Confidence prevails among hospital work departments teams, which positively affects performance), is neutral.

$5)$ In item (4) the weight mean equal " 3.252 " and $p$-value equal " 0.000 " which is less than 0.05 , that (The hospital management supports and encourages the formation of work teams for employees, which positively affects performance), is neutral.

6) In item (5) the weight mean equal " 3.103 " and $p$-value equal " 0.000 " which is less than 0.05 , that (Hospital management focuses on team performance rather than individual performance, which positively affects performance), is neutral (see Table 10). 
Table 10. The impact of administrative empowerment in term of (work teams) on performance in King Abdul-Aziz Hospital in Makkah City.

\begin{tabular}{|c|c|c|c|c|c|c|c|}
\hline No. & Items & Weight mean & standard deviation & Chi-square & $p$-value & Rank & Importance \\
\hline 1 & $\begin{array}{l}\text { In light of the job empowerment in the hospital, the } \\
\text { employees feel that they work within one team, } \\
\text { which positively affects performance }\end{array}$ & 3.748 & 0.624 & 596.79 & 0.000 & 1 & Agree \\
\hline 6 & $\begin{array}{l}\text { The management devised a system of } \\
\text { self-monitoring on the work of individuals and } \\
\text { teamwork, which positively affects performance }\end{array}$ & 3.748 & 0.624 & 105.94 & 0.000 & 2 & Agree \\
\hline 2 & $\begin{array}{l}\text { The ideas and suggestions of employees in light of } \\
\text { their special empowerment are taken seriously when } \\
\text { making decisions regarding their work, which } \\
\text { positively affects performance. }\end{array}$ & 3.515 & 0.615 & 421.30 & 0.000 & 3 & Agree \\
\hline 3 & $\begin{array}{l}\text { Confidence prevails among hospital work } \\
\text { departments teams, which positively affects } \\
\text { performance }\end{array}$ & 3.382 & 0.647 & 393.27 & 0.000 & 4 & Neutral \\
\hline 4 & $\begin{array}{l}\text { The hospital management supports and encourages } \\
\text { the formation of work teams for employees, which } \\
\text { positively affects performance }\end{array}$ & 3.252 & 0.693 & 324.21 & 0.000 & 5 & Neutral \\
\hline 5 & $\begin{array}{l}\text { Hospital management focuses on team performance } \\
\text { rather than individual performance, which positively } \\
\text { affects performance. }\end{array}$ & 3.103 & 0.886 & 180.30 & 0.000 & 6 & Neutral \\
\hline & All items & 3.46 & 0.68 & & & & Agree \\
\hline
\end{tabular}

- Performance of King Abdul-Aziz Hospital in Makkah City (Table 11):

1) In item (5) the weight mean equal " 4.20 " and $p$-value equal " 0.000 " which is less than 0.05, that (Applying the concept of administrative empowerment contributes in creating an effective, healthy work environment, which reflects positively on hospital's performance), is strongly agree.

2 ) In item (4) the weight mean equal " 4.01 " and $p$-value equal " 0.000 " which is less than 0.05 , that (The elements of administrative empowerment contributes in reducing duplication of decisions, which has a positive impact on the hospital's performance), is agree.

3 ) In item (6) the weight mean equal " 3.89 " and $p$-value equal " 0.000 " which is less than 0.05 , that (The elements the administrative empowerment help in accomplishment the required works on time, which has a positive impact on the hospital's performance), is agree.

4) In item (1) the weight mean equal " 3.81 " and $p$-value equal " 0.000 " which is less than .05 , the (The elements of administrative empowerment contribute in improving the health services provided, which reflects positively on the hospital's performance), is agree.

5) In item (2) the weighted mean equal " 3.26 " and $p$-value " 0.000 " which is less than 0.5, the (Applying the elements of administrative empowerment help motivate workers and enhancing their skills, which reflects positively on the hospital's performance), is neutral. 
6) In item (3) the weighted mean equal " 3.11 " and $p$-value " 0.000 " which is less than 0.05, the (Applying the elements of administrative empowerment contributes in reducing medical, administrative errors, which reflects positively on the hospital's performance), is neutral (see Table 11).

\section{Table 12 shows the Terms Order:}

The highest terms was performance with weighted mean (3.71) and importance agree, followed by knowledge teams with weighted mean (3.48) and importance agree, work teams with weighted mean (3.46) and importance agree, finally authorization with weighted mean (3.43) and importance agree. The weighted mean of all terms was (3.52) and importance agree.

There is a difference in the terms based on Years of Practical experience at significance level $\alpha=0.05$ :

We use One way ANOVA test to find these differences in terms due to years of experience, the result illustrated in Table 13 which show that the $p$-value for terms (Work terms, Authorization) is greater than 0.05, that means there is no statistically significant differences at the level of $\alpha=0.05$ in work teams and Authorization, but $p$-value for Knowledge equal (0.023) less than 0.05 this indicate that there is statistically differences between years practical experience at 0.05 level.

Table 11. Performance of King Abdul-Aziz Hospital in Makkah City.

\begin{tabular}{|c|c|c|c|c|c|c|c|}
\hline No. & Items & Weight mean & standard deviation & Chi-square & $p$-value & Rank & Importance \\
\hline 5 & $\begin{array}{l}\text { Applying the concept of administrative } \\
\text { empowerment contributes in creating an effective, } \\
\text { healthy work environment, which reflects positively } \\
\text { on hospital's performance. }\end{array}$ & 4.20 & 1.01 & 242.11 & 0.000 & 1 & $\begin{array}{c}\text { Strongly } \\
\text { agree }\end{array}$ \\
\hline 4 & $\begin{array}{l}\text { The elements of administrative empowerment } \\
\text { contributes in reducing duplication of decisions, } \\
\text { which has a positive impact on the hospital's } \\
\text { performance. }\end{array}$ & 4.01 & 0.90 & 157.41 & 0.000 & 2 & Agree \\
\hline 6 & $\begin{array}{l}\text { The elements the administrative empowerment help } \\
\text { in accomplishment the required works on time, } \\
\text { which has a positive impact on the hospital's } \\
\text { performance. }\end{array}$ & 3.89 & 1.2 & 128.51 & 0.000 & 3 & Agree \\
\hline 1 & $\begin{array}{l}\text { The elements of administrative empowerment } \\
\text { contribute in improving the health services } \\
\text { provided, which reflects positively on the hospital's } \\
\text { performance }\end{array}$ & 3.81 & 0.21 & 462.22 & 0.000 & 4 & Agree \\
\hline 2 & $\begin{array}{l}\text { Applying the elements of administrative } \\
\text { empowerment help motivate workers and enhancing } \\
\text { their skills, which reflects positively on the hospital's } \\
\text { performance. }\end{array}$ & 3.26 & 1.20 & 130.1 & 0.000 & 5 & Neutral \\
\hline 3 & $\begin{array}{l}\text { Applying the elements of administrative } \\
\text { empowerment contributes in reducing medical, } \\
\text { administrative errors, which reflects positively on } \\
\text { the hospital's performance. }\end{array}$ & 3.11 & 0.92 & 144.51 & 0.000 & 6 & Neutral \\
\hline
\end{tabular}


Table 12. The terms order.

\begin{tabular}{cccccc}
\hline No. & terms & Weight mean & standard deviation & Rank & importance \\
\hline 1 & knowledge & 3.48 & 0.61 & 2 & Agree \\
2 & Authorization & 3.43 & 0.71 & 4 & Agree \\
3 & work teams & 3.46 & 0.68 & 3 & Agree \\
4 & Performance & 3.71 & 0.91 & 1 & Agree \\
& All terms & 3.52 & 0.73 & & Agree \\
\hline
\end{tabular}

Table 13. Which show that difference in the terms based on years of practical experience at significance level $\alpha=0.05$.

\begin{tabular}{ccccccc}
\hline \multirow{2}{*}{ A } & S.O.V & Sum of Squares & df & Mean Square & F & $p$-value \\
\hline \multirow{2}{*}{ Knowledge } & Between Groups & 157.616 & 4 & 39.404 & & 0.023 \\
& Within Groups & 4432.290 & 325 & 13.638 & & \\
\hline \multirow{2}{*}{ Authorization } & Between Groups & 19.481 & 4 & 4.870 & 0.775 & 0.542 \\
& Within Groups & 2041.637 & 325 & 6.282 & & 0.409 \\
\hline \multirow{2}{*}{ Work teams } & Between Groups & 20.414 & 4 & 5.103 & & 0.997 \\
& Within Groups & 1663.211 & 325 & 5.118 & & 0.409 \\
\hline
\end{tabular}

There is a difference in the terms based on academic qualification at significance level $\alpha=0.05$ :

We use One way ANOVA test to find these differences in terms due to academic qualification, the result illustrated in Table 14 which show that the $p$-value for each terms is less than 0.05 , that means there is statistically significant differences at the level of $\alpha=0.05$ in each terms.

There is a difference in the terms based on job title at significance level $\alpha$ $=0.05$ :

We use One way ANOVA test to find these differences in terms due to job title, the result illustrated in Table 15 which show that the $p$-value for each terms is less than 0.05 , that means there is statistically significant differences at the level of $\alpha=0.05$ in each terms.

There is a difference in the terms based on gender at significance level $\alpha=$ 0.05:

We use Independent sample t-test to find these differences in terms due to gender, the result illustrated in Table 16 which show that the $p$-value for each terms is greater than 0.05 , that means there is no statistically significant differences at the level of $\alpha=0.05$ in each terms.

There is a difference in the terms based on nationality at significance level $\alpha=0.05$ :

We use Independent sample t-test to find these differences in terms due to nationality, the result illustrated in Table 17 which show that the $p$-value for each terms is less than 0.05 , that means there is statistically significant differences at the level of $\alpha=0.05$ in each term. 
Table 14. Which show difference in the terms based on academic qualification at significance level $\alpha=0.05$.

\begin{tabular}{|c|c|c|c|c|c|c|}
\hline Terms & S.O.V & Sum of Squares & df & Mean Square & $\mathrm{F}$ & $p$-value \\
\hline \multirow{2}{*}{ Knowledge } & Between Groups & 219.896 & 5 & 43.979 & \multirow{2}{*}{3.261} & \multirow{2}{*}{0.007} \\
\hline & Within Groups & 4370.010 & 324 & 13.488 & & \\
\hline \multirow{2}{*}{ Authorization } & Between Groups & 111.161 & 5 & 22.232 & \multirow{2}{*}{3.694} & \multirow{2}{*}{0.003} \\
\hline & Within Groups & 1949.957 & 324 & 6.018 & & \\
\hline \multirow{2}{*}{ Work teams } & Between Groups & 261.476 & 5 & 52.295 & \multirow{2}{*}{11.914} & \multirow{2}{*}{0.000} \\
\hline & Within Groups & 1422.148 & 324 & 4.389 & & \\
\hline
\end{tabular}

Table 15. Which show that difference in the terms based on job title at significance level $\alpha=0.05$.

\begin{tabular}{ccccccc}
\hline Terms & S.O.V & Sum of Squares & df & Mean Square & F & $p$-value \\
\hline \multirow{2}{*}{ Knowledge } & Between Groups & 400.583 & 5 & 80.117 & & \\
& Within Groups & 4189.323 & 324 & 12.930 & 6.196 & 0.000 \\
\hline \multirow{2}{*}{ Authorization } & Between Groups & 347.999 & 5 & 69.600 & & \\
& Within Groups & 1713.119 & 324 & 5.287 & 13.163 & 0.000 \\
& Between Groups & 396.668 & 5 & 79.334 & & \\
\multirow{2}{*}{ Work teams } & Within Groups & 1286.956 & 324 & 3.972 & & \\
& & & & & & \\
\hline
\end{tabular}

Table 16. Which show that difference in the terms based on gender at significance level $\alpha$ $=0.05$.

\begin{tabular}{ccccccc}
\hline Terms & Gender & $\mathrm{N}$ & Mean & Std. Deviation & $\mathrm{T}$ & $p$-value \\
\hline \multirow{2}{*}{ Knowledge } & Male & 267 & 20.4457 & 3.14437 & -0.085 & 0.933 \\
& Female & 63 & 20.5079 & 5.62217 & & 0.353 \\
Authorization & Male & 267 & 19.9101 & 2.47532 & & 0.933 \\
& Female & 63 & 19.5714 & 2.61949 & & 0.202 \\
\hline \multirow{2}{*}{ Work teams } & Male & 267 & 19.3146 & 2.35367 & & 1.282 \\
\hline
\end{tabular}

Table 17. Which show that difference in the terms based on nationality at significance level $\alpha=0.05$.

\begin{tabular}{ccccccc}
\hline \multirow{2}{*}{ Terms } & Nationality & $\mathrm{N}$ & Mean & Std. Deviation & $\mathrm{T}$ & $p$-value \\
\hline \multirow{2}{*}{ Knowledge } & Saudi & 286 & 20.6364 & 3.90150 & & \\
& Non Saudi Arabia & 40 & 19.2250 & 2.01898 & & 0.001 \\
\hline \multirow{2}{*}{ Authorization } & Saudi & 286 & 20.0664 & 2.38691 & 3.495 & 0.001 \\
& Non Saudi Arabia & 40 & 18.4000 & 2.88053 & & \\
\hline \multirow{2}{*}{ Work teams } & Saudi & 286 & 19.3427 & 2.28989 & & 0.031 \\
& Non Saudi Arabia & 40 & 18.5750 & 2.02405 & & 2.209 \\
\hline
\end{tabular}




\section{Results}

Most of individual's Practical experience (from 10 to 15 years) with (47\%), their education as general (Bachelor) with (46.4\%), about 30.3\% from the sample their job is "Doctor", and $80.9 \%$ of them are male, and most of them are Saudi with $86.4 \%$.

1) Individuals agree about the impact administrative empowerment in term of (knowledge) on performance at King Abdul-Aziz Hospital in Makkah, exactly items:

- The working procedures, regulations and instructions are distinguished by clarity and transparency in the hospital, which positively affects performance.

- The hospital administration allows employees to have easy access to information that helps them in work, which reflects positively on performance.

2) Most of individual agree in general about "the impact of administrative empowerment in term of (Authorization) on performance in King Abdul-Aziz Hospital in Makkah" exactly items:

- The hospital administration has a clear strategy for Authorization of power, which reflects positively on performance.

- There are multiple powers for staff to act on the tasks assigned to them, and this positively affects performance.

3) Most of individual agree in general about "the impact administrative empowerment in term of (work team) on performance at King Abdul-Aziz Hospital in Makkah" exactly items:

- In light of the job empowerment in the hospital, the employees feel that they work within one team, which positively affects performance.

- The management devised a system of self-monitoring on the work of individuals and teamwork, which positively affects performance.

4) There are statistically differences between years practical experience at 0.05 level in knowledge.

5) There is a difference in the terms based on academic qualification at significance level 0.05 .

6) There is a difference in the terms based on job title at significance level 0.05 .

7) There is no statistical difference in the terms based on gender and nationality at significance level 0.05 .

8) There are statistically significant differences at the level of 0.05 in each term.

\section{Conclusion}

The researcher extracts the role and the clear effect of administrative empowerment on the performance of health organizations, through this study which focused on the role of Administrative empowerment represented in knowledge, Authorization and work teams and their impact on the performance of King Abdul-Aziz Hospital in Makkah City, where the researcher concluded after analyzing the data obtained from the Hospital, the high levels of performance as a result the administration's interest to the dimensions of empowerment represented in the knowledge of manpower in work, delegation and granting administrative 
powers to workers, and working within the team work, all factors that led to a positive improvement in public performance during the period of this study in the Hospital, and therefore the administration is supposed to maintain those gains that contributed to the improvement of performance, as the researcher concluded during his field study the presence of interest from the management of the King Abdul-Aziz Hospital in excellence in work procedures, regulations, instructions and transparency in administrative work, and this was achieved by a positive development in performance, also in general the administration's interest in improving performance is also inferred because it is reflected on the rest Health organizations, and thus the researcher concludes that empowerment in health organizations is actually a uniform process and enhancing for workers abilities in these organizations to make multiple options and convert those options into procedures, which are those measures that aim to increase the degree of autonomy and self-determination of health organization workers to enable them to represent their interests in a responsible and self-determined manner, based on their own authority, and the researcher has concluded his study Some recommendations that he believes contribute in achieving his goals.

\section{Recommendations}

Based on the study results, the researcher presents the following recommendations that he believes contribute significantly in attaining the study goals, which are summarized as follows: It is necessary to maintain administrative empowerment in terms of (knowledge, Authorization and work teams) due to its positive impact on performance at King Abdul-Aziz Hospital in Makkah City. The need to maintain the excellence achieved by the hospital in work procedures, regulations, instructions and transparency in health reports that reflects positively on performance. Facilitate employees' access to information that helps them in their work, which reflects positively on performance. Extending the scope of Authorization of powers to employees, which will positively reflect on performance. Activating and enhancing work empowerment in the hospital through working within one team, which positively affects performance. It is necessary to maintain a system of self-monitoring of the individual and team work of the hospital and develop it to further improve performance in King Abdul-Aziz Hospital in Makkah City.

\section{Limits of the Study}

This study is determined by the following limits:

1) Subject limits: The Impact of Administrative Empowerment on the Performance of the King Abdul-Aziz Hospital in Makkah City.

2) Spatial limits: The field scope of this study is Saudi Arabia.

3) Place Limits: King Abdul-Aziz Hospital in Makkah City.

4) Time limits: The study will be conducted during the year 2020 .

5) Human boundaries: The population of this study includes the staff of administration, doctors, nurses, technicians. 


\section{Conflicts of Interest}

The authors declare no conflicts of interest regarding the publication of this paper.

\section{References}

Abu Sharkh, N. H. A. R. (2010). Evaluating the Impact of Incentives on the Job Performance Level in the Palestinian Communications Company from the Viewpoint of Employees. Master's Thesis, Gaza: Al-Azhar University in Gaza.

Affana, H. M. (2013). The Administrative Empowerment and Its Relationship with the Effectiveness of the Work Teams in the International NGOs Operating in the Gaza strip. Research Master Degree in Business Administration, Gaza: Al-Azhar University.

Aisha, B. (2016). The Impact of Administrative Empowerment on Organizational Creativity in Small and Medium Enterprises. Case Study of an Institution (Civenco). MA Study in Economic Sciences, Warakla: Kassdi Murbah University.

Akdemir, B., Ederm, O., \& Polat, S. (2010). Characteristics of High-Performance Organization. Journal of Faculty of Economics \&Administrative Sciences, 15, No. 1.

Al Otaibi, N. (2004). Employee Empowerment: As a Management Development Strategy.

Al Shara'a, M. (2009). The Impact of Empowerment on Behaviors of the Official and Additional Role as Seen by Staff at King Founder Abdullah University Hospital. Irbid: Yarmouk University.

Al-Azzawi, N., \& Jawad, A. (2010). Strategic Functions in the Human Resources Department. Amman: Al-Yazouri Scientific House for Publishing and Distribution.

Al-Dawi, A.-S. (2010). Analysis of the Theoretical Foundations of Performance Concept. The Researcher Journal, Issue 7, University of Algeria.

Al-Dosari, S. M. (2014). Administrative Empowerment and Its Relationship to Job Satisfaction with the Heads of Government Secondary Schools in the City of Riyadh from Their Point of View. Faculty of Education Journal, 25, Issue 98.

Al-Madhi, A., \& Nusairat, F. (2011) The Impact of Administrative Empowerment on the Application of Total Quality Management in the University of Jordan Hospital. Jordan Journal, 7 , Issue 4.

Al-Madi, T. A. (2011). The Effect of Administrative Empowerment on the Application of Comprehensive Quality Management in the University of Jordan Hospital, a Case Study. The Jordanian Journal of Business Administration, 7 , Issue 4.

Al-Magableh, M. Q., \& Otoum, A. M. (2014). The Administrative Empowerment and its Relationship with the Innovative Behavior among the Head/Coordinators of the Academic Department at the Faculty of Science and Arts, Sharurah-Najran University. International Research in Education, 2, No. 2. https://doi.org/10.5296/ire.v2i2.6298

Al Otaibi, J. (2013). The Effect of Employees' Empowerment in Improving Their Job Performance.

Al-Rabadi, T. I. (2009). Empowerment of Employees and Its Impact on Institutional Performance in Independent Public Institutions in Jordan. Unpublished Master Thesis, Amman: Amman Arab University for Graduate Studies.

Al-Rashoudi, K. S. (2009). Elements of Empowerment in Educational Security Organizations and Their Readiness to Implement It. Unpublished Master Thesis, Riyadh: Naif Arab University for Security Sciences. 
Al-Ruwaiq, M. (2016). Administrative Empowerment for Leaders of General Education Schools in Afif Governorate. International Specialized Educational Journal, 5, Issue 8.

Al-Sabti, L. A., \& Quraishi, M. A.-T. (2015). The Effect of Administrative Empowerment on Achieving Job Satisfaction among Employees at the University of Muhammad Khaider, Biskra. Jordanian Journal of Business Administration, 11, Issue 1.

Al-Sakhle, A. et al. (2010). Organizational Culture and Its Impact on the Level of Job Performance in the Nablus Municipality. MA Study, Gaza: Al-Najah National University.

Al-Sharif, A. H. R. A. (2015). The Reality of Administrative Empowerment of Female Principals and Its Relationship to the Professional Development of Female Teachers in Secondary Schools in the City of Makkah Al-Mukarramah. MA Study in Educational Administration and Planning. Makkah: Department of Educational Administration and Planning, Faculty of Education, Umm Al-Qura University.

Baird, K., \& Wang, H. Y. (2009). Employee Empowerment: Extent of Adoption and Influential Factors. Personnel Review, 39, No. 5. https://doi.org/10.1108/00483481011064154

Brown, D. R., \& Harvery, D (2006). An External Approach to Organizational Development. Upper Saddle River, NJ: Prentice Hall.

Carter, J. D. T. (2009). Managers Empowering Employees. American Journal of Economics and Business Administration, 1, 41-46. https://doi.org/10.3844/ajebasp.2009.41.46

Forrester, R. (2000). Empowerment Rejuvenating a Potent Idea. Academy of Management Perspectives, 14, No. 3. https://doi.org/10.5465/ame.2000.4468067

Gittell, J. H., Fairfield, K., Bierbaum, B., Jackson, R., Kelly, M., Laskin, R., Lipson, S., Siliski, J., Thornhill, T., \& Zuckerman, J. (2010). Impact of Relational Coordination on Quality of Care, Postoperative Pain and Functioning, and Length of Stay. A Nine Hospital Study of Surgical Patients.

Harrim, M. H., \& Alkshali, S. J. (2008). Employees Empowerment and Its Effect on Team Effectiveness: Gordon. Journal of Business firms Administration, 4, No. 1.

Hassan, S. S. M. (2008). The Effect of Different Leadership Styles on the Degree of Empowerment Employees. Unpublished Master Thesis, Cairo: Cairo University.

Henkin, A. (2005). Teacher-Principal Relationships: Exploring Linkage between Empowerment and Interpersonal Trust. Journal of Educational Administrative, 43, 260-277.

Irechukwu, N. E. (2010). School Management Positions and Women Empowerment-A Rwandan Case. International. Journal of Business and Management, 5, No. 6.

Jankowicz, A. D. (2005). Business Research Projects (4th ed.). London: Thomson Learning.

Karen, L. (2006). 4 Keys to Employee Empowerment. Lansdale, PA: Lawson Consulting Group Inc.

Kothari, C. R. (2004). Research Methodology, Methods \& Techniques. New Delhi: New Age International Limited.

Kruja, D. et al. (2009). The Levels of Empowerment Impact on the Level of Job Satisfaction: The Case of Albanian Hotels. TMC Journal, 4, No. 2.

Latifa, B. (2015). The Impact of Empowering Employees on Improving Performance in Health Institutions, a Comparative Study between Public Hospitals and Private Hospitals of Biskra.

Liszt, A. R. (2008). Perceiving Empowered Leadership: A Qualitative Exploration of New York City Principals, Experience with Decision-Making Authority In Empowerment Schools. The Degree of Doctor, New York: Columbia University.

Littrell, R. (2003). Employee Empowerment in China, Case Study. Auckland: Auckland University of Technology. 
Melhem, Y. S. (2006). Empowerment as a Contemporary Management Concept. Cairo: Arab Organization for Administrative Development.

Mohammadia, O. G. A. R. (2016). The Effect of Functional Empowerment on the Creativity Behaviour of the Employees in the Jordan Tourism Board. Master in Business Administration, Amman: Middle East University.

Mustafa, D. (2016). Relationship between Employee Empowerment and Organizational Stress: A Research on Hospital Employees, International Journal of Scientific Study Serape Taşkaya, 3, Issue 12 .

Mutawi, D. M., \& Khalifa, H. J. (2014). Principles of Research and Skills in Educational, Psychological and Social Sciences. Riyadh: Al Mutanabi Library, Kingdom of Saudi Arabia.

Obeid, O. F. K. (2009). The Reality of Empowerment Management on the Performance of Workers in the Palestinian Ministry of Health. An Unpublished Master Study.

Ozaralli, N. (2003). Effects of Transformational Leadership on Empowerment and Team Effectiveness. Leadership \& Organization Development Journal, 24, 335-344. https://doi.org/10.1108/01437730310494301

Pandey, P., \& Pandey, M. M. (2015). Research Methodology Tools and Techniques. Romania: Bridge Center.

Ranjit Kumar (2011). Research Methodology, a Step-by-Step Guide for Beginners (3rd ed.). New Delhi: SAGE Publishers Ltd.

Ratmawati, D. (2007). Managerial Competency and Management to Employee Empowerment: Banking Companies Case. Proceeding of the 13th Asia Practice Management Conference, Melbourne.

Talib, A.-N. (2014). The Impact of Administrative Empowerment on Organizational Performance in Private Hospitals in Amman. Unpublished Master Study, Amman: Middle East University.

Tjosvold, D., \& Sun, H. F. (2006). Effect of Power Concepts and Employee Performance on Managers' Empowering. Leadership \& Organization Development Journal, 27, No. 3. https://doi.org/10.1108/01437730610657730

Turner, J. T. (2006). Relationships between Location in the Hierarchy Span of Control, and Industry Type on Perceptions of Empowerment. M.S. Dissertation, Denton, TX: University of North Texas.

Yang, S.-B., \& Choi, S. O. (2009). Employee Empowerment and Team Performance: Autonomy, Responsibility, Information and Creativity. Team Performance Management, 15, No. 5/6. https://doi.org/10.1108/13527590910983549

Yoon, J., Kim, M., \& Shin, J. (2016). Confidence in Delegation and Leadership of Registered Nurses in Long-Term Hospitals, Journal of Nursing Management, 24, 676-685. https://doi.org/10.1111/jonm.12372 


\section{Questionnaire}

\section{Demographic Data:}

1) Years of Practical experience.
( ) $1-<5$ years
( ) $5-<10$ years
( ) $10-<15$ years
( ) $\geq 15$ years

2) Academic qualification

( ) Secondary ( ) Bachelor

3) Job Title:

( ) Doctor

( ) Specialist

( ) Higher diploma

( ) Master ( ) PhD.

technician

( ) Employee

4) Gender:

( ) Male ( ) Female

5) Nationality:
( ) Saudi
( ) Non-Saudi

Dimension I: The impact administrative empowerment in term of (knowledge) on performance at King Abdul-Aziz Hospital in Makkah City.

\begin{tabular}{cccc}
\hline Items & $\begin{array}{c}\text { Strongly } \\
\text { Agree }\end{array}$ & Agree Neutral Disagree & $\begin{array}{c}\text { Strongly } \\
\text { Disagree }\end{array}$ \\
\hline
\end{tabular}

The hospital administration allows employees to have easy access to information that helps them in work, which reflects positively on performance

The hospital administration provides effective and advanced means of communication for employees, which reflects positively on performance

There is a management information system that provides information quickly in the hospital, and this reflects positively on performance

The workers share the new knowledge with the workers in other departments, which has a positive impact on performance

The working procedures, regulations and instructions are distinguished by clarity and transparency in the hospital, which positively affects performance

The hospital administration encourages workers to be creative and to develop their cognitive abilities, which positively affects performance

Dimension II: The impact of administrative empowerment in term of (Authorization) on performance in King Abdul-Aziz Hospital in Makkah City.

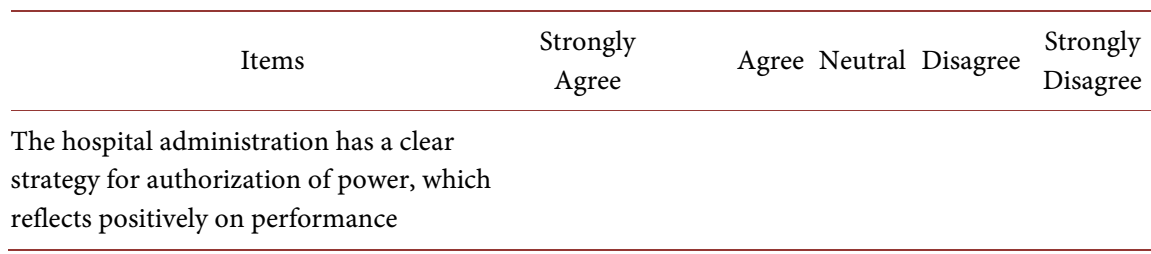




\section{Continued}

The powers granted are commensurate with the nature of jobs for the employees, which reflects positively on performance

The hospital administration believes in participating in decision-making by delegating executive and middle management and involving them in decision-making

The hospital staff, in the light of authorization granted to them, diagnose problems and propose solutions, choose and evaluate them

The hospital administration is confident in the staff s abilities to perform the tasks assigned to them, which reflects positively on the performance

There are multiple powers for staff to act on the tasks assigned to them, and this positively affects performance

Dimension III: The impact of administrative empowerment in term of (work teams) on performance in King Abdul-Aziz Hospital in Makkah City.

\begin{tabular}{cccc}
\hline Items & $\begin{array}{c}\text { Strongly } \\
\text { Agree }\end{array}$ & Agree Neutral Disagree & $\begin{array}{c}\text { Strongly } \\
\text { Disagree }\end{array}$
\end{tabular}

In light of the job empowerment in the hospital, the employees feel that they work within one team, which positively affects performance

The ideas and suggestions of employees in light of their special empowerment are taken seriously when making decisions regarding their work, which positively affects performance.

Confidence prevails among hospital work departments teams, which positively affects performance

The hospital management supports and encourages the formation of work teams for employees, which positively affects performance

Hospital management focuses on team performance rather than individual performance, which positively affects performance

The management devised a system of self-monitoring on the work of individuals and teamwork, which positively affects performance 
Dimension IV: Performance of King Abdul-Aziz Hospital in Makkah City.

\begin{tabular}{cccc}
\hline Items & $\begin{array}{c}\text { Strongly } \\
\text { Agree }\end{array}$ & Agree Neutral Disagree & $\begin{array}{c}\text { Strongly } \\
\text { Disagree }\end{array}$ \\
\hline
\end{tabular}

The elements of administrative empowerment contribute in improving the health services provided, which reflects positively on the hospital's performance

Applying the elements of administrative empowerment help motivate workers and enhancing their skills, which reflects positively on the hospital's performance

Applying the elements of administrative empowerment contributes in reducing medical, administrative errors, which reflects positively on the hospital's performance

The elements of administrative empowerment contribute in reducing duplication of decisions, which has a positive impact on the hospital's performance.

Applying the concept of administrative empowerment contributes in creating an effective, healthy work environment, which reflects positively on hospital's performance

The elements the administrative empowerment help in accomplishment the required works on time, which has a positive impact on the hospital's performance 